\title{
EMPLOYEE PERCEPTIONS OF HRM AND TQM AND THE EFFECTS ON \\ SATISFACTION AND INTENTION TO LEAVE
}

\section{Paul Boselie and Ton Van der Wiele}

\begin{tabular}{|l|l|}
\hline \multicolumn{2}{|l|}{ ERIM REPORT SERIES RESEARCH IN MANAGEMENT } \\
\hline ERIM Report Series reference number & ERS-2001-42-ORG \\
\hline Publication & July 2001 \\
\hline Number of pages & 13 \\
\hline Email address corresponding author & Vanderwiele@few.eur.nl \\
\hline Address & Erasmus Research Institute of Management (ERIM) \\
& Rotterdam School of Management / Faculteit Bedrijfskunde \\
& Erasmus Universiteit Rotterdam \\
& P.O.Box 1738 \\
& 3000 DR Rotterdam, The Netherlands \\
& Phone: +31 10 408 1182 \\
& Fax: $\quad+31104089640$ \\
& Email: info@erim.eur.nl \\
& Internet: $\quad$ www.erim.eur.nl \\
\hline
\end{tabular}

Bibliographic data and classifications of all the ERIM reports are also available on the ERIM website: www.erim.eur.nl 


\title{
ERASMUS RESEARCH INSTITUTE OF MANAGEMENT
}

\author{
REPORT SERIES \\ RESEARCH IN MANAGEMENT
}

\begin{tabular}{|c|c|c|}
\hline \multicolumn{3}{|c|}{ BIBLIOGRAPHIC DATA AND CLASSIFICATIONS } \\
\hline Abstract & \multicolumn{2}{|c|}{$\begin{array}{l}\text { There is a growing interest in theory and in practice with regard to the relationship between } \\
\text { human resource management [HRM] and total quality management [TQM] as well as the } \\
\text { relationship between these two perspectives and business performances. Empirical research } \\
\text { suggests significant effects of HRM/TQM on the performances of an organisation. The majority } \\
\text { of research in this area is focused on the effects of HRM/TQM at the organisational level. } \\
\text { Research on the perceptions of individual employees might obtain new insights for further } \\
\text { discussion on the effectiveness of HRM/TQM in an organisation. The authors have the } \\
\text { opportunity to analyse a relatively large database with recent data of individual employee } \\
\text { perceptions from a knowledge-intensive organisation in The Netherlands. This analysis gives } \\
\text { new insight in relation to concepts like 'co-operation', 'information', 'leadership', 'salary',' 'work } \\
\text { conditions', and 'goal setting' in relation to employee satisfaction and the intention to leave the } \\
\text { organisation. }\end{array}$} \\
\hline \multirow{3}{*}{$\begin{array}{l}\text { Library of Congress } \\
\text { Classification } \\
(\text { LCC) }\end{array}$} & $5001-6182$ & Business \\
\hline & $\begin{array}{l}5546-5548.6 \\
5548.7-5548.85\end{array}$ & $\begin{array}{l}\text { Office Organization and Management } \\
\text { Industrial Psychology }\end{array}$ \\
\hline & $\begin{array}{l}\text { HD 66+ } \\
\text { HF 5549.5.P35 }\end{array}$ & $\begin{array}{l}\text { Quality circles management } \\
\text { Performance standards ( Personnel management ) }\end{array}$ \\
\hline \multirow{3}{*}{$\begin{array}{l}\text { Journal of Economic } \\
\text { Literature } \\
\text { (JEL) }\end{array}$} & $\mathrm{M}$ & Business Administration and Business Economics \\
\hline & $\begin{array}{l}\text { M } 10 \\
\mathrm{~L} 2\end{array}$ & $\begin{array}{l}\text { Business Administration: general } \\
\text { Firm Objectives, Organization and Behaviour }\end{array}$ \\
\hline & M 12 & Personnel Management \\
\hline \multirow{3}{*}{$\begin{array}{l}\text { European Business Schools } \\
\text { Library Group } \\
\text { (EBSLG) }\end{array}$} & $85 \mathrm{~A}$ & Business General \\
\hline & $\begin{array}{l}100 B \\
240 B\end{array}$ & $\begin{array}{l}\text { Organization Theory (general) } \\
\text { Information Systems Management }\end{array}$ \\
\hline & $\begin{array}{l}120 M \\
260 \mathrm{G}\end{array}$ & $\begin{array}{l}\text { Performance Appraisal } \\
\text { Quality Management }\end{array}$ \\
\hline \multicolumn{3}{|c|}{ Gemeenschappelijke Onderwerpsontsluiting (GOO) } \\
\hline \multirow[t]{3}{*}{ Classification GOO } & 85.00 & Bedrijfskunde, Organisatiekunde: algemeen \\
\hline & $\begin{array}{l}85.05 \\
85.08\end{array}$ & $\begin{array}{l}\text { Management organisatie: algemeen } \\
\text { Organisatiesociologie, organisatiepsychologie }\end{array}$ \\
\hline & $\begin{array}{l}85.62 \\
85.12\end{array}$ & $\begin{array}{l}\text { Personeelsbeleid } \\
\text { Kwaliteitsmanagement }\end{array}$ \\
\hline \multirow[t]{3}{*}{ Keywords GOO } & \multicolumn{2}{|c|}{ Bedrijfskunde / Bedrijfseconomie } \\
\hline & \multicolumn{2}{|c|}{ Organisatieleer, informatietechnologie, prestatiebeoordeling } \\
\hline & \multicolumn{2}{|c|}{ Personeelsbeleid, Kwaliteitszorg, Prestatiebeoordeling, Arbeidstevredenheid } \\
\hline Free keywords & \multicolumn{2}{|c|}{ Employee morale; Human Resources Management (HRM); Total Quality Management (TQM) } \\
\hline
\end{tabular}




\title{
Employee perceptions of HRM and TQM and the effects on satisfaction and intention to leave
}

\author{
Paul Boselie and Ton van der Wiele
}

Paul Boselie is Ph.D. student and researcher of the Department of Business and Organisation at the Rotterdam School of Economics, The Netherlands. His research is focused on the relationship between human resource management and business performance. He will finish his Ph.D. research at the end of 2001.

Ton van der Wiele is associate professor in the Department of Business and Organisation at the Rotterdam School of Economics, The Netherlands. During the last ten years, he has been involved in the area of quality management. He has presented his research projects at conferences all over the world and published in various international journals.

\begin{abstract}
There is a growing interest in theory and in practice with regard to the relationship between human resource management [HRM] and total quality management [TQM] as well as the relationship between these two perspectives and business performances. Empirical research suggests significant effects of HRM/TQM on the performances of an organisation. The majority of research in this area is focused on the effects of HRM/TQM at the organisational level. Research on the perceptions of individual employees might obtain new insights for further discussion on the effectiveness of HRM/TQM in an organisation. The authors have the opportunity to analyse a relatively large database with recent data of individual employee perceptions from a knowledge-intensive organisation in The Netherlands. This analysis gives new insight in relation to concepts like 'co-operation', 'information', 'leadership', 'salary', 'work conditions', and 'goal setting' in relation to employee satisfaction and the intention to leave the organisation.
\end{abstract}

Keywords: Employee morale; Human Resources Management [HRM]; Total Quality Management [TQM] 


\section{Employee perceptions of HRM and TQM and the effects on satisfaction and intention to leave}

Paul Boselie and Ton van der Wiele

\section{Introduction}

There is a growing interest in theory ${ }^{1}$ and in practice $^{2}$ with regard to the relationship between human resource management [HRM] and total quality management [TQM] as well as the relationship between these two approaches and business performances. Prior empirical research [see for an overview e.g. Delery and Doty, 1996; Reed et al, 1996; Guest, 1997; Boselie et al, 2001] suggests significant effects of HRM/TQM on the performances of an organisation. The majority of research in this area is focused on the effects of HRM/TQM at the organisational level [Arthur, 1994; Huselid, 1995; MacDuffie, 1995; Choi et al, 1998; Wiele van der, 1998; Hendricks and Singhal, 2001]. In practice this means that the human resource manager or the quality manager is asked to fill in a questionnaire, most often one list of questions representing the whole organisation. Research on the perceptions of individual employees might give another new stimulus to the discussion on the effectiveness of HRM/TQM in an organisation [Guest, 1999]. The authors have the opportunity to analyse a relatively large database [N=2313] with recent data [survey 2000] of individual employee perceptions from a Dutch company called Ernst \& Young. This analysis gives new insight in relation to concepts like 'co-operation', 'information', 'leadership', 'salary', 'work conditions', and 'goal setting' in relation to employee satisfaction and the intention to leave the organisation.

\section{HRM/TQM and business performance}

Paauwe and Richardson [1997] give an overview of prior research on the relationship between HRM and business performance, and make a clear distinction between HRM results [e.g. satisfaction, motivation, absenteeism, retention, trust and involvement] and hard business performance indicators like profit and sales volume. HRM activities like attracting new employees and selection, personnel planning and rewarding, all 
have an effect on HRM results. Some of these HRM activities have a direct effect on business performances. The HRM results have a direct effect on the business performance as such. For example, a high level of sick leave will automatically lead to higher costs for the organisation and thus, lower profits. In some situations there will be a reverse causality between HRM activities and business performances. For example, higher profits can lead to a higher level of willingness to invest in HRM activities, e.g. training of employees. Furthermore, we can see that situational or contingency factors [e.g. size and history of the organisation, branch, level of technology] have an impact on [a] HRM activities, [b] HRM results, and on [c] business performance.

In the TQM literature there seems to be general understanding regarding the type of TQM activities that contribute to the development of 'business excellence'. Dale [1999] enumerates the following practices relevant to organisational excellence form a TQM perspective: leadership, training, involvement and participation of employees, co-operation and customer focus. Most of these themes can be found also in current HRM literature.

Various authors indicate explicitly so-called 'best practices' that will deliver sustainable competitive advantage for the organisation. Pfeffer [1994] discerns 16 of 'high performance' practices, amongst those 'information', 'high wages', and 'job security'. Arthur [1994] focuses on 'decentralisation', 'participative leadership' and 'excellent wages'. The business excellence models defined in relation to the international and national quality awards, stimulated the development of best practices from a TQM point of view [Blackburn et al, 1993; Puay et al, 1998]. The authors of this paper have the possibility to focus on the relationship between HRM/TQM practices and business performance in a Dutch organisation [while most of the available research has done in a USA or UK context]; and on the perception of individual employees within the organisation [in stead of the organisational level which is the focus of most of the prior research]; and on the relationship between HRM/TQM practices and HRM/TQM results [in stead of the effects on frequently used result variables e.g. profit, sales volume and productivity]. The key question in this research is: what is the contribution of employee perceptions regarding HRM/TQM practices on HRM/TQM results, i.e. job satisfaction and intention to leave the organisation? 


\section{Employee morale survey in Ernst \& Young}

Ernst \& Young is an international organisation with accounting activities and consultancy on tax issues. Related to these two scopes Ernst \& Young delivers a number of specialisms, e.g. edp-auditng, interim management, corporate finance, actuarial consulting, law services, security management, and crisis management, forensic services, foundation trust services, advisory consultancy, human resources services, recruitment $\&$ assessment services, advice on company location choices, and services on information and documentation systems. Worldwide the organisation has approximately 83,500 employees, spread over 700 locations, in more than 130 countries, with an annual sales volume of US\$ 10.9 billion.

Once every two years a large scale employee morale survey is organised amongst all employees [managers and non-managers, staff and partners] in The Netherlands, with the support of ISR - International Survey Research [London, UK]. ISR is an internationally operating organisation with the advantage of making comparisons of the survey results with those of other companies or 'best in class'. The survey in 2000 led to a response group of approximately 2300 records [response rate was 50\%].

\section{Analysis}

The questionnaire survey used in 2000 in The Netherlands covers approximately 200 items, which are grouped around: personal information [age, gender, type of contract], perception of employees on HRM/TQM policies, and result variables, e.g. overall job satisfaction and intention to leave the organisation. The first step in the analysis of the responses is focused on the selection of items from the questionnaire which relate to current theoretical HRM/TQM concepts ${ }^{3}$. In essence, this means a selection and categorisation of items based on our own expertise in the area of human resource management and total quality management. By doing this, we are able to identify the following [possible] constructs: 'information', 'salary \& secondary work conditions', 'co-operation \& teamwork', 'leadership', 'customer focus', 'appraisal', 'training \& development', and 'goalsetting'.

The second step is to identify items from the questionnaire that can be linked to those theoretical constructs. Because we did not develop the questionnaire ourselves and 
therefore are limited to the existing material, we could not make use of all items. We selected 45 items that in our opinion fit the theoretical constructs. Through factor analysis on this set of 45 items we find most of the theoretical constructs, although some of the items have been deleted, because they did not load on the statistical factors. The use of factor analysis [principal component analysis] gives some methodological and practical advantages ${ }^{4}$. The second step resulted in nine underlying factors covering 38 items [using five point scales $^{5}$ ] from the questionnaire:

[1] format of information delivery [cronbach alpha $=0.821]$

[2] insight in goals and objectives [cronbach alpha $=0.845$ ]

[3] secondary work conditions [cronbach alpha $=0.809$ ]

[4] co-operation within [business] units [cronbach alpha $=0.809$ ]

[5] information sharing [cronbach alpha $=0.692$ ]

[6] leadership [ cronbach alpha $=0.830$ ]

[7] customer focus [cronbach alpha $=0.683$ ]

[8] co-operation between [business] units [cronbach alpha $=0.629$ ]

[9] salary [cronbach alpha $=0.775$ ]

Some theoretical constructs, that have been identified in the first step ['appraisal', 'teamwork', and 'training \& development'], did not deliver reliable and validated constructs in the dataset. An overview of the items and the underlying factors is given in table 1.

Table 1: Independent HRM/TQM variables

[1] information delivery format [7 items, cronbach alpha $=0.821$, mean $=3.89$, s.d. $=0.64$ ]

a. E\&Y informs employees in an excellent way about things that are relevant to them;

b. Within E\&Y employees are properly informed by e-mail about matters that are relevant to them through Email;

c. Within E\&Y employees are properly informed by 'NL-info' about matters that are relevant to them;

d. Within E\&Y employees are properly informed by office and group meetings about matters that are relevant to them;

e. Within E\&Y employees are properly informed by an internal newsletter called 'Verspreid Verbonden' about matters that are relevant to them;

f. Within E\&Y employees are properly informed by the 'OR-database' about matters that are relevant to them;

g. Within E\&Y employees are properly informed by other sources of information about matters that are relevant to them.

[2] insight in goals and objectives $[4$ items, cronbach alpha $=0.845$, mean $=3.63$, s.d. $=0.84$ ]

a. I have sufficient insight in the objectives of my direct work environment;

b. I have sufficient insight in the objectives of my office;

c. I have sufficient insight in the objectives of E\&Y; 
d. I have sufficient insight in the objectives of my business unit.

[3] secondary work conditions $[4$ items, cronbach alpha $=0.809$, mean $=3.50$, s.d. $=0.83]$

- $\quad$ E\&Y pays a lot of attention to important developments in the society and its secondary work conditions reflect those developments, regarding

a. working part-time;

b. parental leave;

c. child care;

d. tele-working.

[4] co-operation within [business] units $[4$ items, cronbach alpha $=0.809$, mean $=3.94$, s.d. $=0.72$ ]

a. E\&Y stimulates co-operation;

b. E\&Y appreciates co-operation;

c. Exchange of knowledge within E\&Y is actively promoted;

d. Exchange of knowledge within E\&Y is appreciated sufficiently.

[5] information sharing [4 items, cronbach alpha $=0.692$, mean $=3.18$, s.d. $=0.85$ ]

a. I am well informed about the developments within E\&Y on the issue of life-balance;

b. I am well informed about the plans of various [business] units within E\&Y;

c. I am well informed about the results of various [business] units within E\&Y;

d. I am well informed about a specific recent merger.

[6] leadership [3 items, cronbach alpha $=0.830$, mean $=3.84$, s.d. $=0.94$ ]

a. My direct supervisor is available whenever I need him/her;

b. My direct supervisor communicates effectively;

c. My direct supervisor stimulates the development of skills of people.

[7] customer focus $[4$ items, cronbach alpha $=0.683$, mean $=3.82$, s.d. $=0.70]$

a. I/my group/unit gets feedback on customer satisfaction regarding the work done;

b. The importance given by my office/group/unit to customer service is visible in our daily work;

c. My group/unit continuously tries to understand the demands and expectations of its customers;

d. My group/unit properly reacts to customer demands.

[8] co-operation between [business] units $[4$ items, cronbach alpha $=0.629$, mean $=3.40$, s.d. $=0.64$ ]

a. Within E\&Y there is sufficient co-operation between the operations and support groups;

b. Within E\&Y there is sufficient co-operation between offices/groups/units;

c. Within E\&Y there is sufficient co-operation between the various country organisations;

d. Within E\&Y there is sufficient co-operation between the various business units.

[9] salary $[4$ items, cronbach alpha $=0.775$, mean $=3.54$, s.d. $=0.90$ ]

a. I think I'm not getting underpaid in comparison to colleagues within E\&Y;

b. Regarding the work I do, I am not getting underpaid;

c. As far as I know, salary within E\&Y is equal as or even better than in comparable organisations;

d. Our secondary work conditions are equal to or better than in other organisations.

Scale: 1 = disagree, 2 = more disagree than agree, 3 = neither disagree nor agree, 4 = more agree than disagree, 5 = agree; Mean

$=$ mean score of the variable/construct; s.d. $=$ standard deviation.

Cronbach alpha is a measure for the internal consistency of the items, that together cover the specific (new and underlying) factor. In general, a value of 0.65 is 
acceptable. Only our construct 'co-operation within [business] units' is just below that level with a cronbach alpha of 0.64 , although only slightly.

The questionnaire included also a number of control variables which are used in our analysis [see table 2]: age of the employee [8 categories], gender [male/female], married or living together [yes/no], partner works too [yes/no], employee has children still at home [yes/no], type of contract $[100 \%, 80 \%$ or part time contract], and tenure with E\&Y [7 categories]. Some observations on the control variables are: $69 \%$ of the respondents is aged less than $35 ; 38 \%$ is female, and $69 \%$ is married or lives together; $79 \%$ of the respondents has a partner who also has a job, indicating that there is a high percentage of employees with double income; $73 \%$ of respondents has a full time contract, $12 \%$ a so-called $80 \%$-contract and $15 \%$ has a part time contract; $32 \%$ of the respondents has children at home; $41 \%$ of the respondents has a tenure of more than 5 years with E\&Y.

Table 2: Control variables

\begin{tabular}{|c|c|}
\hline Age: & $\begin{array}{l}<25 \text { year }[16.9 \%] ; 25-30 \text { year }[31.4 \%] ; 30-35 \text { year }[20.8 \%] ; 35-40 \text { year }[10.6 \%] ; 40- \\
45 \text { year }[6.1 \%] ; 45-50 \text { year }[5.2 \%] ; 50-55 \text { year }[5.7 \%] ;>55 \text { year }[3.2 \%]\end{array}$ \\
\hline Gender: & Male $61.8 \%[$ dummy $=1]$; Female $38.2 \%[$ dummy $=0]$ \\
\hline Married/living together: & Yes $69.3 \%$ [dummy = 1]; No 30.7\% [dummy = 0] \\
\hline Partner works too: & Yes $79.4 \%[$ dummy $=1]$; No $20.6 \%[$ dummy $=0]$ \\
\hline Children at home: & Yes $31.6 \%$ [dummy =1]; No 68.4\% [dummy $=0]$ \\
\hline Contract: & Full time contract $73.0 \% ; 80 \%$ contract $12.2 \%$; Part time contract $14.8 \%$ \\
\hline Tenure: & $\begin{array}{l}<6 \text { months } 8.5 \% ; 6 \text { months }-1 \text { year } 7.3 \% ; 1-3 \text { year } 27.0 \% ; 3-5 \text { year } 16.3 \% ; 5-10 \\
\text { year } 15.0 \% ; 10-15 \text { year } 12.0 \% ;>15 \text { year } 13.8 \%\end{array}$ \\
\hline
\end{tabular}

The dependent variables [HRM/TQM results] in this analysis are 'employee satisfaction' and 'intention to leave the organisation'. Employee satisfaction is a construct or factor [cronbach alpha $=0.811]$ using five items from the questionnaire covering satisfaction with his/her job, the way individuals are treated, appreciation and general satisfaction with the work and the organisation. The intention to leave is measured with one question: "do you have the serious intention at this moment to change employer?" [yes $=1$; no=0]. The descriptives show that $12 \%$ of the respondents has at the moment of the survey, a serious intention to leave the organisation and look for another employer [the dependent variables are summarised in table 3]. 
Table 3: Dependent variables

Employee satisfaction [5 items, cronbach alpha $=0.811$, mean $=4.00$, s.d. $=0.58$ ]:

a. Level of satisfaction with the job security;

b. Level of satisfaction with honest and respectful treatment;

c. Level of satisfaction with appreciation for the way you do your work;

d. I would recommend $\mathrm{E} \& \mathrm{Y}$ as a good organisation to work for;

e. Level of general satisfaction with E\&Y.

Intention to leave the organisation:

- do you have the serious intention at this moment to change employer?

Yes $11.8 \%$ [Yes $=1]$; No $88.2 \%$ [No $=0]$

In order to reduce the level of data, in figure 4 only the correlations between the HRM/TQM constructs and the HRM/TQM results are summarised. 'Co-operation between [business] units' [0.31***], 'leadership' [0.36***] and 'salary' [0.32***] reveal strong significant correlations with employee satisfaction. All the other constructs reveal positive significant correlations with employee satisfaction, although at a less stronger level. We have to be careful with these results, because in large datasets [in this case $\mathrm{N}>2300$ ] all relations have a tendency to become significant. From the correlation matrix we can also conclude that a higher level of employee satisfaction is correlated with a lower level of having the intention to leave the organisation $[-0.38 * * *]$. Looking at the correlations between the HRM/TQM constructs and the intention to leave the organisation, we find that most correlations are significant, although there is not a very strong correlation. High scores on 'salary' [-0.15***], 'leadership' [-0.15***], and 'insight in goals and objectives' [-0.15***] reveal the relative strongest relation with the intention to leave. 
Table 4: Correlations between HRM/TQM constructs and results

\begin{tabular}{|c|c|c|}
\hline & $\begin{array}{l}\text { Employee } \\
\text { Satisfaction }\end{array}$ & $\begin{array}{l}\text { Intention } \\
\text { to leave }\end{array}$ \\
\hline - Intention to leave & $-0.38 * * *$ & 1.00 \\
\hline [1] format of information delivery & $0.10 * * *$ & $-0.06 *$ \\
\hline [2] insight in goals and objectives & $0.19 * * *$ & $-0.15 * * *$ \\
\hline [3] secondary work conditions & $0.07 * *$ & $-0.07 * *$ \\
\hline [4] co-operation within [business] units & $0.31 * * *$ & $-0.13 * * *$ \\
\hline [5] information sharing & $0.15^{* * *}$ & -0.01 \\
\hline [6] leadership & $0.36^{* * *}$ & $-0.15 * * *$ \\
\hline [7] customer focus & $0.10 * * *$ & $-0.11 * * *$ \\
\hline [8] co-operation between [business] units & $0.11 * * *$ & $-0.11 * * *$ \\
\hline [9] salary & $0.32 * * *$ & $-0.15 * * *$ \\
\hline
\end{tabular}

$* \mathrm{P}<0.05, * * \mathrm{P}<0.01, * * * \mathrm{P}<0.001$

For analysis of the effects of HRM/TQM constructs on employee satisfaction, we use OLS [ordinary least squares]. With an adjusted $\mathrm{R}^{2}$ of 0.41 and a F-value of 50,706 [p<0.001] we may conclude that model [1] has a reasonable fit [see table 5]. It is concluded from this analysis that high scores on HRM/TQM constructs [e.g. 'cooperation within [business] units', 'leadership', and 'salary'] lead to high scores on employee satisfaction. We also find that older employees are more satisfied than younger employees, females are more satisfied than males, and employees with children at home are more satisfied than employees without.

For analysis of the effects of HRM/TQM constructs on the intention to leave the organisation, we use logistic regression, as a result of the nature of this dependent variable [a dummy with value ' 0 ' or ' 1 ']. All the HRM/TQM constructs reveal a negative relationship with the intention to leave, except for the construct 'information sharing' [see model 2 in table 5]. 
Table 5: Regression of HRM/TQM constructs and the dependent variables

\begin{tabular}{|c|c|c|}
\hline & Model [1] & Model [2] \\
\hline & Satisfaction & Intention to leave \\
\hline & {$[\mathrm{OLS}]$} & [Log regression] \\
\hline constant & -0.04 & $2.18 * * *$ \\
\hline [1] format of information delivery & $0.07 * *$ & $-0.19 *$ \\
\hline [2] insight in goals and objectives & $0.18^{* * *}$ & $-0.42 * * *$ \\
\hline [3] secondary work conditions & $0.06 * *$ & $-0.20 *$ \\
\hline [4] co-operation within [business] units & $0.28 * * *$ & $-0.39 * * *$ \\
\hline [5] information sharing & $0.14 * * *$ & 0.01 \\
\hline [6] leadership & $0.33 * * *$ & $-0.39 * * *$ \\
\hline [7] customer focus & $0.10^{* * *}$ & $-0.29 * * *$ \\
\hline [8] co-operation between [business] units & $0.11 * * *$ & $-0.40 * * *$ \\
\hline [9] salary & $0.32 * * *$ & $-0.47 * * *$ \\
\hline Age & $0.08 *$ & 0.01 \\
\hline Gender & $-0.08 * *$ & 0.12 \\
\hline Married/living together & 0.05 & 0.35 \\
\hline Partner works too & 0.09 & -0.04 \\
\hline Children at home & $0.05^{*}$ & $-0.30 * *$ \\
\hline Full time contract & - & $-0.40 *$ \\
\hline $80 \%$ contract & 0.00 & $-0.32 *$ \\
\hline Part time contract & -0.02 & - \\
\hline Tenure & -0.03 & 0.02 \\
\hline$\overline{\mathrm{R}^{2}}$ & 0.42 & - \\
\hline Adjusted $\mathrm{R}^{2}$ & 0.41 & - \\
\hline $\mathrm{F}$ & $50,706^{* * *}$ & - \\
\hline chi-square & - & $148,779 * * *$ \\
\hline
\end{tabular}

$* \mathrm{p}<0.05, * * \mathrm{p}<0.01, * * * \mathrm{p}<0.001$

The independent variables in this analysis are standardised

The constructs 'salary', 'insight in goals and objectives', 'co-operation between units', 'co-operation within units', 'leadership' and 'customer focus' all seem to be important with respect to the intention to leave the organisation. The construct 'secondary work conditions' does not seem to be as important as the others, although we expected the items covered by this construct [work in part time; parental leave; child care; and tele-work] to be more important nowadays, when taking into account the percentage of employees with double income [79\% of respondents in this study], 
and the percentage of employees with children at home [32\% of respondents in this study]. Table 5 [model 2] also reveals that employees with children at home have less intentions to leave the organisation, as so for employees with a full time or $80 \%$ contract versus part time workers. The chi-square value for model 2 indicates that the fit is acceptable.

\section{Conclusion and discussion}

The analysis reveals that a positive perception of individual employees on the HRM/TQM concepts leads to a higher level of satisfaction and less intentions to leave the organisation. 'Co-operation within units', 'leadership' and 'salary' show strong significant effects on employee satisfaction. It has also been shown that a satisfied employee has less intentions to leave the organisation and change employer. This is especially important in a time of a tight labour market and is consistent with the importance given by employers to reduce turnover rates. Low scores on 'salary', 'insight in goals and objectives', 'co-operation within and between units', 'leadership' and 'customer focus' all seem to stimulate the employee to look for another employer. Therefore, in order to keep the employees in the organisation, you have to create demanding jobs [co-operation and customer focus], supportive management and a coaching style of management [leadership], clear views on the objectives of the organisation [insight in goals] and a good payment structure [salary]. These conclusions are consistent with HRM [e.g. Pfeffer, 1994] and TQM theory [e.g. Dale et al, 1997].

The authors realise that there also are some limitations to this research. Firstly, we use a cross-sectional analysis, so it is necessary to be cautious in conclusions regarding causality. Secondly, we analyse data from one specific organisation in a specific sector; other sectors might give other results. Thirdly, the research methodology might lead to questioning the validity and reliability of the constructs; to be more confident about our methodology and the constructs we found, we also analysed the data from an earlier survey [1998] and found extremely strong evidence for the same HRM/TQM constructs and for the conclusions from the 2000 survey. Further more we will give a follow-up to our analysis with an analysis of the next survey [2002] to even strengthen our approach. 
In the literature we see human resource management and total quality management becoming more interlined. One reason is that both perspectives use the same theoretical paradigms and assumptions, e.g. in relation leadership, motivation of employees, involvement of employees, teamwork and training. Another reason is the tendency to link both perspectives with business performance as well in theory as in practice. Furthermore, service organisations [compared to manufacturing] are becoming more important in Western world, and continuous improvement has to be linked stronger to the people issues [the most important asset in service organisations]. This might end in a syntheses of human resource management and total quality management, leading to a broader theme of performance management. Performance management we can define then as "the way employees are managed to achieve organisational goals, leading to sustainable competitive advantage". A fruitful co-operation between HRM and TQM can give new theoretical insights and practical implications. Further empirical research on the causality between theoretical constructs therefore is necessary. The aim is to use empirical data to test theoretical and conceptual assumptions and to translate the conclusions into practice.

\section{Notes}

1. A growing interest in the relationship between HRM/TQM and business performance can be traced back through: [1] special issues of academic journals as Decision Science [5:26, 1995], The Academy of Management Journal [4:39, 1996], The International Journal of Human Resource Management [3:8, 197, Human Resource Management [Fall, 1997, and The Human Resource Management Journal [Fall, 1999]; [2] seminars and conferences as the HRM Conference in Rotterdam [September, 1995], The ESRC Seminars in England [1996], and parallel sessions of the Academy of Management Meeting [1998, 1999 and 2000]; [3] publications in top ranked journals [e.g. Arthur, 1994; Huselid, 1995; MacDuffie, 1995].

2. We see a growing attention for management data and especially employee management data. Information technology makes it possible to gather more data regarding employees [e.g. age, education levels, absenteeism]. We also see more attention for employee satisfaction surveys and the results being translated into policies and actions regarding reducing turnover rates, balance between work and private, employability and evaluation of programs that focus on business excellence.

3. The constructs from step 1 are built on: Arthur's [1994] control versus commitment HRM systems; Pfeffer's [1994] 16 best practices; Huselid's [1995] 13 HRM practices; and Dale's [1999] key principles of TQM.

4. Methodological and practical advantages: data reduction leading to better overview [from 38 items to 9 constructs/factors]; connection towards policy implications is made easier; the 9 constructs are maximally independent from each other.

5. Scale: $1=$ disagree, $2=$ more disagree than agree, $3=$ neither disagree nor agree, $4=$ more agree than disagree, $5=$ agree. 


\section{References}

Arthur J.B. (1994), 'Effects of Human Resource Systems on Manufacturing Performance and Turnover', Academy of Management Journal, 3(37): 670-87.

Blackburn R. and Rosen B. (1993), 'Total Quality and Human Resources Management: Lessons learned from Baldrige Award winning companies', Academy of Management Executives, 3(7):43-65.

Boselie P., Paauwe J. and Jansen P.G.W. (forthcoming in 2001), 'Human Resource Management \& Performance: lessons from the Netherlands', The International Journal of Human Resource Management.

Choi T.Y. and Eboch K. (1998), 'The TQM paradox: Relations among TQM practices, plant performance, and customer satisfaction', Journal of Operations Management, 1(17): 59-75.

Dale B.G., Cooper C.L., Wilkinson A. (1997), Managing Quality \& Human Resources; A Guide to continuous improvement, Blackwell, Oxford.

Dale B.G. (1999), Managing Quality, $3^{\text {rd }}$ edition, Blackwell Publishers, Oxford.

Delery J.E. and Doty D.H. (1996), 'Modes of Theorising in Strategic Human Resource Management: Tests of universalistic, contingency, and configurational performance predictions', Academy of Management Journal, 4(39): 802-35.

Guest D.E. (1999), 'Human Resource Management - The Workers' Verdict', Human Resource Management Journal, 3(9): 5-25.

Hendricks K.B. and Singhal V.R. (2001), 'The long-run stock price performance of firms with effective TQM programs', Management Science, 3(47): 359-68.

Huselid, M.A. (1995), 'The Impact of Human Resource Management Practices on Turnover, Productivity, and Corporate Financial Performance', Academy of Management Journal, 3(38):635-72.

MacDuffie J.P. (1995), 'Human Resource Bundles and Manufacturing Performance: Organisational Logic and Flexible Production Systems in the World Auto Industry', Industrial and Labour Relations Review, 2(48): 197-221.

Paauwe J. and Richardson R. (1997), Introduction Special Issue on HRM and Performance, The International Journal of Human Resource Management, 3(8): 260.

Pfeffer J. (1994), Competitive Advantage Through People. Boston: Harvard Business School Press.

Reed R., Lemak D.J. and Montgomery J.C. (1996), 'Beyond process: TQM content and firm performance', Academy of Management Review, 1(21): 173-202.

Puay S.H., Tan K.C., Xie M. and Goh T.N. (1998), 'A comparative study of nine national quality awards', The TQM Magazine, 1(10): 30-9.

Wiele van der A. (1998), Beyond Fads; Management fads and organisational change with reference to quality management, Eburon, Delft.

\section{Word counts: 4,443 words.}




\title{
Publications in the ERIM Report Series Research ${ }^{*}$ in Management
}

\author{
ERIM Research Program: "Organizing for Performance"
}

\section{1}

Employee Perception on Commitment Oriented Work Systems: Effects onTrust and Perceived Job Security

Paul Boselie, Martijn Hesselink, Jaap Paauwe \& Ton van der Wiele

ERS-2001-02-ORG

The Emergence of a Private Business Sector in China: The Case of Zhejiang

Barbara Krug \& Hans Hendrischke

ERS-2001-03-ORG

Contingent Employment in the Netherlands

Ferrie Pot, Bas Koene \& Jaap Paauwe

ERS-2001-04-ORG

Under Construction. (Idendities, Communities and Visual Overkill)

Slawomir Magala

ERS-2001-17-ORG

The Dutch Banking Chipcard Game: Understanding a Battle between Two Standards

Henk J. de Vries \& George W.J. Hendrikse

ERS-2001-18-ORG

Empirical Evidence for the relation between customer satisfaction and business performance?

Ton van der Wiele, Paul Boselie \& Martijn Hesselink

ERS-2001-32-ORG

On the emergence of growers' associations: self-selection versus market power

G.W.J. Hendrikse \& W.J.J. Bijman

ERS-2001-34-ORG

Employee perceptions of HRM and TQM and the effects on satisfaction and intention to leave

Paul Boselie \& Ton van der Wiele

ERS-2001-42-ORG

\section{0}

Critical Complexities, from marginal paradigms to learning networks

Slawomir Magala

ERS-2000-02-ORG

Marketing Cooperatives and Financial Structure: a Transaction Costs Economics Analysis

George W.J. Hendrikse \& Cees P. Veerman

ERS-2000-09-ORG

A Marketing Co-operative as a System of Attributes: A case study of VTN/The Greenery International BV, Jos Bijman, George Hendrikse \& Cees Veerman

ERS-2000-10-ORG

* A complete overview of the ERIM Report Series Research in Management:

http://www.ers.erim.eur.nl

ERIM Research Programs:

LIS Business Processes, Logistics and Information Systems

ORG Organizing for Performance

MKT Marketing

F\&A Finance and Accounting

STR Strategy and Entrepreneurship 
Marketing Co-operatives: An Incomplete Contracting Perspective

George W.J. Hendrikse \& Cees P. Veer man

ERS-2000-13- ORG

Ownership Structure in Agrifood Chains: The Marketing Cooperative

George W.J. Hendrikse \& W.J.J. (Jos) Bijman

ERS-2000-15-ORG

Organizational Change and Vested Interests

George W.J. Hendrikse

ERS-2000-17-ORG

Is Polder-Type Governance Good for You? Laissez-Faire Intervention, Wage Restraint, And Dutch Steel

Hans Schenk

ERS-2000-28-ORG

Foundations of a Theory of Social Forms

László Pólos, Michael T. Hannan \& Glenn R. Carroll

ERS-2000-29-ORG

Reasoning with partial Knowledge

László Pólos \& Michael T. Hannan

ERS-2000-30-ORG

The Strawberry Growth Underneath the Nettle: The Emergence of Entrepreneurs in China

Barbara Krug \& Lászlo Pólós

ERS-2000-34-ORG

Trading Virtual Legacies

Slawomir Magala

ERS-2000-36-ORG

The Interdependence between Political and Economic Entrepeneurship

Barbara Krug

ERS-2000-43-ORG

Ties that bind: The Emergence of Entrepreneurs in China

Barbara Krug

ERS-2000-44-ORG

Human Resource Management and Performance: Lessons from the Netherlands

Paul Boselie, Jaap Paauwe \& Paul Jansen

ERS-2000-46-ORG

Possible futures for the HR function in different market

Roger Williams, Jaap Paauwe \& Anne Keegan

ERS-2000-54-ORG

Quantity versus Quality in Project Based Learning Practices

Anne Keegan \& J. Rodney Turner

ERS-2000-55-ORG

The Management of Innovation in Project Based Firms

Anne Keegan and J. Rodney Turner

ERS-2000-57-ORG

Learning by Experience in the Project-Based Organization

J. Rodney Turner, Anne Keegan \& Lynn Crawford

ERS-2000-58-ORG 